\title{
Glass Ampoules: Risks and Benefits
}

\author{
Antônio Roberto Carraretto, TSA ${ }^{1}$, Erick Freitas Curi, TSA ${ }^{2}$, Carlos Eduardo David de Almeida ${ }^{3}$, \\ Roberta Eleni Monteiro Abatti ${ }^{4}$
}

\begin{abstract}
Summary: Carraretto AR, Curi EF, Almeida CED, Abatti REM - Glass Ampoules: Risks and Benefits.
Background and objectives: Glass ampoules have been widely used in packaging injection drugs. Glass has important characteristics that allow it to be widely used in fabrication of recipients for drugs and other sterile substances. However, contamination of solutions with glass microparticles on breaking open glass ampoules, the presence of metals, percutaneous injury, and biological contamination justify the need of educational materials to orient the manipulation of ampoules.
\end{abstract}

Contents: Glass microparticles generated in the snap-opening of ampoules, as well as metals that contaminate their contents can be aspirated and injected through several routes. Exogenous contaminations by glass and metals can reach several sites in the organism. They trigger organic reactions that may give rise to injuries. Opening ampoules can expose professionals to the risk of percutaneous injuries. These lesions increase the biological risk as they are the gateway for viruses and bacteria. Ampoules opening systems (VIBRAC and OPC) have been developed to reduce the incidence of such accidents. Alternative materials to glass may represent an interesting strategy to increase safety. The use of prefilled syringes may represent an evolution regarding safety.

Conclusions: Team training and information provided by the pharmaceutical industry on the use of ampoules are fundamental in the prophylaxis of accidents and contaminations. The search for safer materials to replace glass is also important.

Keywords: Disposable Equipment; Glass; Anesthesiology; Education, Medical, Continuing; Safety Management.

[Rev Bras Anestesiol 2011;61(4): 513-521] @Elsevier Editora Ltda.

\section{INTRODUCTION}

Glass ampoules have been widely used for drugs. Anesthesiologists, along with nurses and nurse aides, represent a significant proportion of the group of professionals that routinely manipulate this material.

Glass is made of basically three inorganic compounds $\left(\mathrm{SiO}_{2}-73 \% ; \mathrm{Na}_{2} \mathrm{CO}_{3}-14 \% ; \mathrm{CaCO}_{3}-11 \%\right)$. In essence, it is colorless. During its manufacture metallic oxides (iron, cobalt, manganese, nickel, aluminum, chrome, arsenic, barium, and others) are added. Many of these metallic oxides can give color to glass ${ }^{1}$.

Glass has important characteristics that are responsible for its wide use in the manufacture of containers for drug and other sterile substances (Table I).

Received from Universidade Federal do Espírito Santo. Hospital Universitário Cassiano Antônio Moraes - HUCAM/UFES, Brazil.

1. PhD in Anesthesiology at UNESP; Professor of the Departamento de Clínica Cirúrgica da UFES; Responsible for the CET Integrado HUCAM/HAFPES

2. President of Sociedade de Anestesiologia do Espírito Santo - SAES. Co-responsible for the CET Integrado HUCAM/HAFPES; Assisting Physician of Serviço de Anestesiologia do HUCAM - UFES

3. Anesthesiology Specialist (TEA - MEC/SBA), and from Universidade de São Paulo

(USP); Assisting Physician of Serviço de Anestesiologia do HUCAM - UFES

4. Resident in Anesthesiology at the CET Integrado HUCAM/HAFPES

Submitted on September 13, 2010.

Approved on January 24, 2011.

Correspondence to:

Rua Erothildes Penna Medina, 301/1202

Praia da Costa

29101375 - Vila Velha, ES, Brazil

E-mail: erickcuri@superig.com.br
Contamination of ampoule contents with glass particles is common upon the opening of some types of ampoules. This has been observed and reported for a long time by the scientific community ${ }^{2}$. The small glass fragments may be injected through several administration routes. Anesthesiologists may administer these particles both intravascular and in the epidural and subarachnoid spaces. Glass particles may also carry some metals used in their manufacture ${ }^{1,3}$. Contamination by these tiny particles requires a long time for the development of injuries. Through animal studies, it was possible to demonstrate that infusion of glass microparticles resulted in pulmonary silicosis and nodular fibrosis of the liver, spleen, and the small bowel. These lesions resulted from mechanis$\mathrm{ms}$ of foreign body reactions and embolisms ${ }^{4}$. It has been demonstrated that the main source of drug contamination by metals are their own packages. This is due to the migration of metal used in fabrication of ampoules into the recipient. Once exogenous contamination by metals (barium, aluminum, and others) occurs, they reach several sites in the organism ${ }^{5}$. Cellular defense mechanisms react to this aggression and as a consequence several toxic effects may be seen. The quality and intensity of the clinical manifestations are directly proportional to the toxic load and contamination time.

The number of glass microparticles that contaminate the solution in ampoules, upon opening, varies in proportion to the size of the ampoule and the opening orifice ${ }^{2}$. Strategies have been created in an attempt to avoid the administration of microparticles to patients. Some authors have investigated the use of filters in needles, as well as the use of smaller caliber needles. These studies did not demonstrate any evidence of protection. Nonetheless, it was possible to demonstrate that 
Table I - Important Characteristics of Glass as an Adequate

Material for Drugs

\begin{tabular}{|c|c|}
\hline Characteristics & Importance \\
\hline They can filter specific wave lengths & Packaging of photosensitive substances \\
\hline Impermeability & Important barrier between media \\
\hline Smooth surface & Easy to clean \\
\hline Rigidity and stability & Withstands vacuum \\
\hline
\end{tabular}

the use of filter syringe increased costs significantly, besides retaining some drugs, such as insulin and vincristine sulphate ${ }^{2,6,7}$. Some benefits on aspirating substances to be injected in the subarachnoid space have been demonstrated.

In addition to problems with glass microparticles contamination, and indirectly with some metals, special attention should be directed towards occupational risk. Opening ampoules may expose professionals to percutaneous injuries. These lesions can represent an important biological risk as they may be gateways for bacteria and viruses. Ampoule packaging may also represent a potential source of microbial infection for patients. Several measures dedicated to risk prevention, such as the use of gloves, gauze, ampoule openers, as well as disinfection of ampoules with $70 \%$ alcohol before opening are available to professionals handling such vessels ${ }^{8,9}$. Currently, it is possible to acquire some ampoules in sterile packages ${ }^{9}$.

Facilitator mechanisms for breaking ampoule have been developed in an attempt to decrease percutaneous injuries

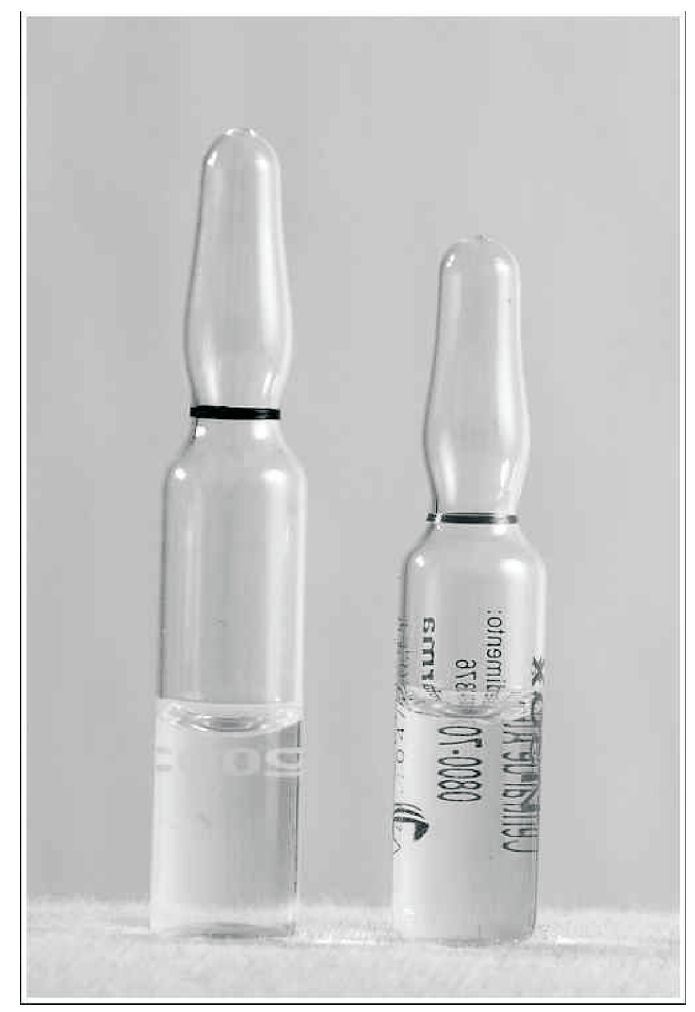

Figure 1 -VIBRAC System. and contamination of contents. Among them, the "rupturedisk" (VIBRAC) and "OPC" (One-Point Cut Ampoules) should be mentioned. In Brazil, VIBRAC is the most common system (Figure 1). This mechanism can be found in $85 \%$ of ampoules. It implies applying a ring of paint after the cure/tempera process of ampoule manufacture. It partially penetrates in the glass, causing fragility of the area of application. This fragility is located at the strangulation point of the ampoule (between the head and body of the ampoule). The OPC system (Figure 2) is used in other national fabrications. In this system, a small incision is made in the strangulation area of the ampoule. A small point of paint is placed a few millimeters above the incision. This point orients the correct opening position. Even with these two facilitator mechanisms, accidents still occur. Most often, they are secondary to the lack of training and lack of adequate information in the leaflet of medication. Table II compares the advantages of each of those systems ${ }^{10,11}$.

Figure 3 shows a safe way of opening ampoules with facilitating systems.

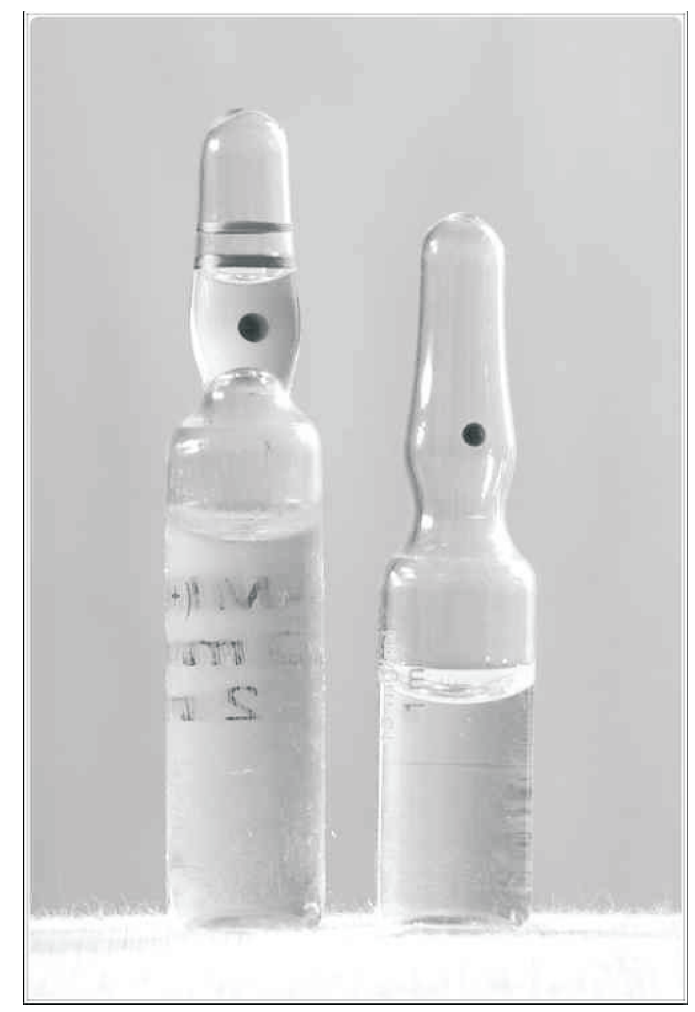

Figure 2 -OPC System. 
Table II - Comparison of the Advantages of Facilitating Systems to Break Open Ampoules

\begin{tabular}{ll}
\hline VIBRAC & OPC \\
\hline Simpler manufacture process & Dye, along with glass particles, does not detach into the ampoule \\
$\begin{array}{l}\text { Several possible positions to } \\
\text { break open ampoules }\end{array}$ & A $50 \%$ reduction in the tension force of rupture \\
& Less probability of generating sharp edge vertical projections at the break point
\end{tabular}

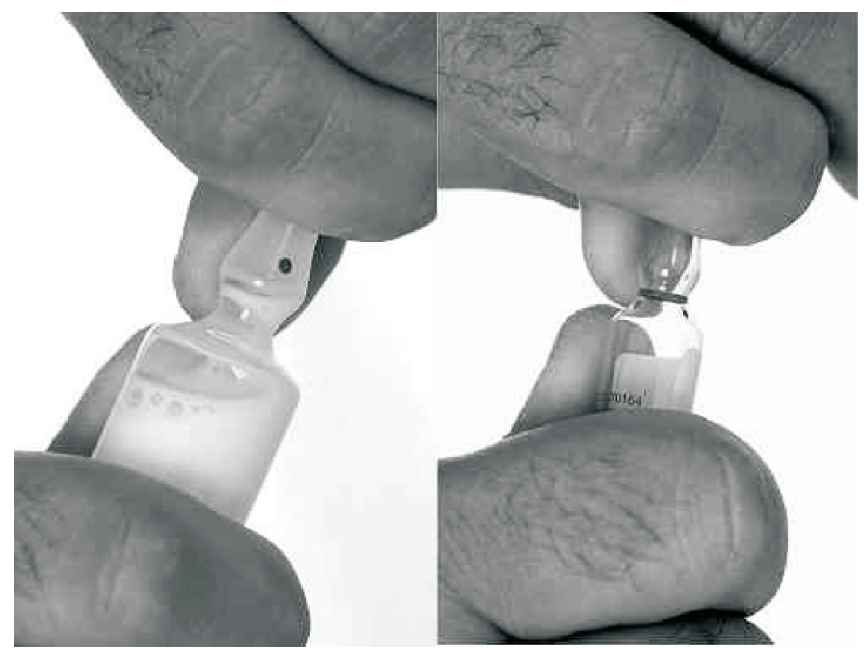

Figure 3 - 1. Maintaining the Ampoule at a $45^{\circ}$ Angle (minimizes the risk of wasting the substance and contamination with microparticles). 2. Thumbs (support on the strangulation), index fingers (they should involve the upper part of the ampoule) - Pressure. 3. OPC - Thumbs should be opposite to the point.

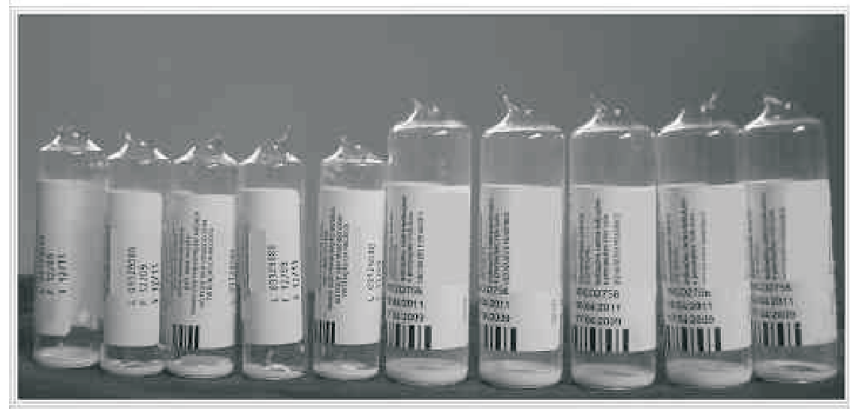

Figure 5 - Vertical Projections on the Opening Border of Propofol Ampoules (10 and $20 \mathrm{~mL}$ ).

In specific cases, such as manipulation of ampoules containing chemotherapeutic agents, gloves are recommended. Ampoules should always be discarded in recipients for sharp edge materials.

Regarding the risk of professionals that manipulate ampoules, there is an important flaw on breaking open some of them. After opening, there is a tendency to produce sharp edge vertical projections that increase the risk of injuries. Larger ampoules and with a greater orifice are at greater risk of producing such projections. This is due to the greater irregularity of their opening border ${ }^{11,12}$. Since 1997, notable irregularities on the opening border of propofol ampoules (Figure 4) have been questioned ${ }^{11}$. In the present study, propofol ampou-

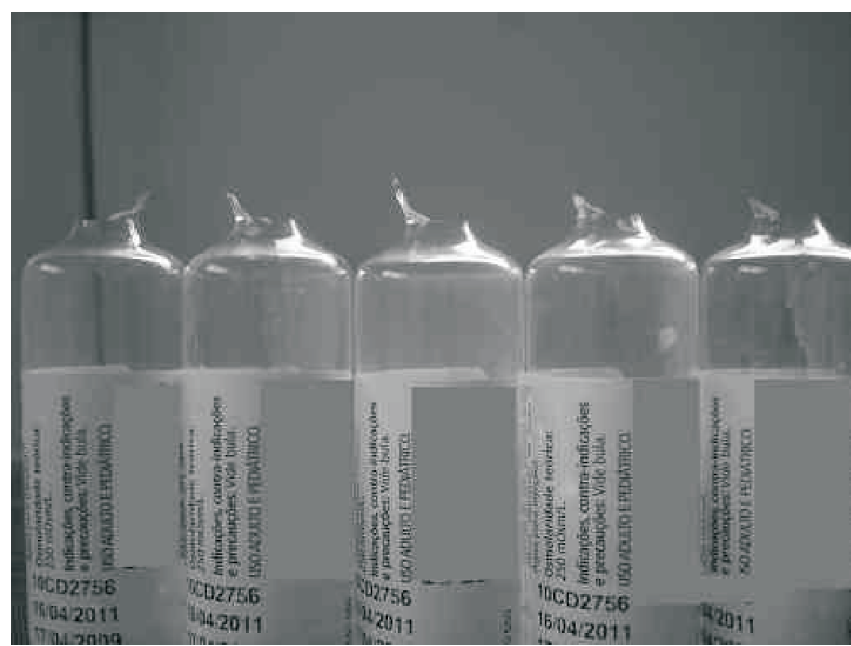

Figure 4 - Vertical Projections on the Opening Border.

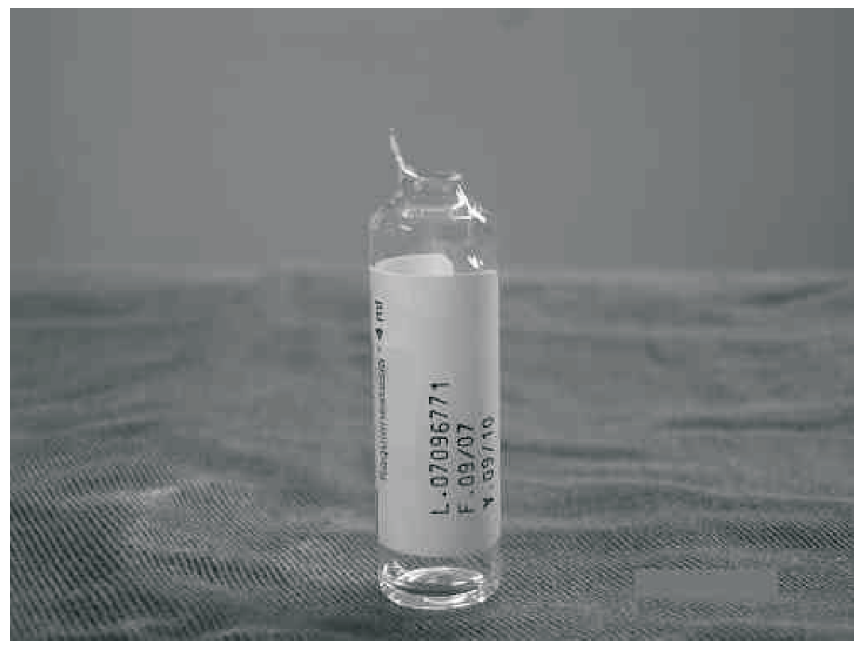

Figure 6 - Vertical Projections on the Opening Border of a $4 \mathrm{~mL}$ Ampoule.

les used during a working day were analyzed. They all were opened according to safety determinations (Figure 5). Lower volume ampoules, although less common, also can produce vertical projections (Figure 6). Even in view of this fact, leaflets of six commercial representatives of propofol were investigated. Only in two cases it was possible to detect orientations to open the ampoule. Approximately $6 \%$ of anesthesiologists had hand injuries from opening glass ampoules. Twenty-six per cent of these professionals had scars on their hands due 
to the same cause. With loss of continuity provoked by these injuries, skin contamination with blood and secretions allow a proper environment for the development of several infections ${ }^{13}$. Even though, a large number of anesthesiologists is negligent regarding gloves in their daily activity. The use of this safety apparatus would prevent $98 \%$ of the contact with blood and secretions ${ }^{8}$. Several excuses are used to justify this attitude. Among them are loss of tactile sensitivity, bad habit, convenience, discomfort, lack of adequate training and knowledge of about the risks, in addition to difficulty in manipulating adhesive tapes ${ }^{14}$. A recent study demonstrated that a policy of mandatory use of gloves was associated with a significant reduction in the incidence of percutaneous injuries with needles, ampoules and others, and in the level of contamination in the workplace of anesthesiologists. Gloves resulted in a significant reduction of percutaneous injuries with a lower incidence of contamination with occult blood on monitor surfaces, anesthesia equipment, and personal materials such as pens and glasses ${ }^{8,15}$. Other methods to avoid hand injuries include industrialized devices created especially for opening ampoules. On a Letter to the Editor in the journal Anesthesia and Analgesia, anesthesiologists proposed improvised methods to open ampoules and reduce the risk of percutaneous injuries. Those methods range from the "elbow" of ventilatory systems to the use of syringes without their plungers 6,12,16.

Alternative materials to glass may be an interesting option to increase safety. Packing drugs in a plastic bag has also been gaining followers. Plastic (Polyvinyl Chloride - PVC; Polypropylene - PP; Ethyl Vinyl Acetate - EVA) is an orga- nic product. It is constituted by carbon, hydrogen, oxygen, nitrogen, and halogen atoms. This polymer is not inert and can be subjected to degradation and oxidation. Therefore, the addition of anti-oxidants, stabilizers, plasticizers and others is necessary ${ }^{17}$. An occasional interaction between parenteral drugs and plastic components hinder the generalized use of this material in the manufacture of such containers. As an example, we could mention diazepam ${ }^{18}$, nitroglycerin ${ }^{19}$, isosorbide dinitrate, and warfarin sodium. They can all be absorbed by PVC. The availability of these drugs is decreased when they are in plastic containers or administered through plastic infusion sets ${ }^{21}$.

The use of prefilled sterilized syringes may represent an evolution regarding professional safety minimizing occasional mistakes in diluting solutions, as well as the risk of contamination. Multi-dose vials are also part of this strategy of risk reduction. However, they also present disadvantages ${ }^{23,24}$, such as the need for preservatives, greater probability of bacterial contamination, and the use of latex in the aspiration mechanism.

We conclude that training and additional information from the pharmaceutical industry regarding the use of ampoules are fundamental in the prophylaxis of accidents and contaminations. Thus, studies on the discovery of new systems of breaking open ampoules are necessary. The objective of these studies should be the creation of systems that produce a reduced number of fragments and using less force to break open ampoules. 


\section{REFERÊNCIAS / REFERENCES}

01. Shelby JE - Introduction to glass science and technology, 2 Ed., Cambridge, Royal Society of Chemistry, 2005;72-108.

02. Carbone-Traber KB, Shanks CA - Glass particle contamination in single-dose ampules. Anesth Analg, 1986;65:1361-1363.

03. Pavanetto F, Genta I, Conti B et al. - Aluminium, cadmium and lead in large volume parenterals: contamination levels and sources. Int J Pharmaceutics, 1989;54:143-148.

04. Garvan JM, Gunner BW - The harmful effects of particles in intravenous fluids. Med J Aust, 1964;2:1-6.

05. Bohrer D, Nascimento $P C$, Binotto $R$ et al. - Investigação sobre a origem do alumínio em soluções de nutrição parenteral. Rev Bras Nutr Clin, 2003;18:47-56.

06. Russell SH - Glass ampules - another approach. Anesth Analg, 1994;78:816

07. Waller DG, George CF - Ampoules, infusions and filters. Br Med J (Clin Res Ed), 1986;292:714-715.

08. Ben-David B, Gaitini L - The routine wearing of gloves: impact on the frequency of needlestick and percutaneous injury and on surface contamination in the operating room. Anesth Analg, 1996;83:623-628.

09. Hemingway $\mathrm{CJ}$, Malhotra $\mathrm{S}$, Almeida $\mathrm{M}$ et al. - The effect of alcohol swabs and filter straws on reducing contamination of glass ampoules used for neuroaxial injections. Anaesthesia, 2007;62:286-288.

10. Anônimo - Evite acidentes em abertura de ampolas. Revista COREN - SP, 2007; (71):19.

11. Stewart PC - A persistent problem with glass ampoules. Anaesthesia, 1997;52:509-510.

12. Gallacher BP - Glass ampules. Anesth Analg, 1993;77:399-400.

13. Parker MR - The use of protective gloves, the incidence of ampoule injury and the prevalence of hand laceration amongst anaesthetic personnel. Anaesthesia, 1995;50:726-729. 
14. Tiefenthaler W, Gimpl S, Wechselberger G et al. - Touch sensitivity with sterile standard surgical gloves and single-use protective gloves. Anaesthesia, 2006;61:959-961.

15. Kristensen MS, Sloth E, Jensen TK - Relationship between anesthetic procedure and contact of anesthesia personnel with patient body fluids. Anesthesiology, 1990;73:619-624.

16. Weenig CS - A better, safer, an inexpensive way to open glass ampules. Anesthesiology, 1998;88:838.

17. Mano EB - Introdução aos Polímeros, 2 Ed., São Paulo, Edgar Blucher, 1985.

18. Ball D, Tisocki K - PVC bags considerably reduce availability of diazepam. Cent Afr J Med, 1999;45:105.

19. Treleano A, Wolz G, Brandsch R et al. - Investigation into the sorption of nitroglycerin and diazepam into PVC tubes and alternative tubes materials during application. Int J Pharm, 2009;369:30-37.

20. De Muynck C, Colardyn F, Remon JP - Influence of intravenous administration set composition on the sorption of isosorbide dinitrato. J Pharm Pharmacol, 1991;43:601-604.

21. Martens HJ, De Goede PN, Van Loenen AC - Sorption of various drugs in polyvinyl chloride, glass, and polyethylene - lined infusion containers. Am J Hosp Pharm, 1990;47:369-373.

22. Longfield R, Longfield J, Smith LP et al. - Multidos medication vial sterility: an in-use study and a review of the literature. Infect Control, 1984;5:165-169.

23. Schubert A, Hyams KC, Longfield RN - Sterility of anesthetic multipledose vials after opening. Anesthesiology, 1985;62:634-636.

Resumen: Carraretto AR, Curi EF, Almeida CED, Abatti REM - Ampollas de Vidrio: Riesgos y Beneficios.

Justificativas y objetivos: Las ampollas de vidrio han sido extensamente utilizadas en el acondicionamiento de fármacos. El vidrio presenta importantes características que le dan la posibilidad de usarse ampliamente en la fabricación de recipientes en el acondicionamien- to de fármacos y otras sustancias estériles. Sin embargo, la contaminación de las soluciones con micropartículas de vidrio durante la abertura, la presencia de metales, los accidentes perforo-cortantes y las contaminaciones biológicas, justifican la necesidad del uso de materiales educativos que orienten sobre la manipulación de esas ampollas.

Contenido: Las micropartículas de vidrio generadas en la abertura de las ampollas pueden ser aspiradas e inyectadas en las más diversas vías, como también los metales que contaminaron el contenido de esas ampollas. Las contaminaciones exógenas por vidrios y metales pueden alcanzar diversos sitios en el organismo. Se desencadenan entonces reacciones orgánicas que pueden originar lesiones. Abrir ampollas puede exponer al profesional al riesgo de lesiones perforocortantes. Esas lesiones aumentan el riesgo biológico porque son la puerta de entrada para los virus y las bacterias. Algunos sistemas de abertura de ampollas (VIBRAC Y OPC), fueron desarrollados para reducir la incidencia de tales accidentes. Los materiales alternativos al vidrio pueden representar una estrategia interesante para aumentar la seguridad. El uso de jeringuillas esterilizadas y preparadas con anterioridad por el fabricante, podría ser una especie de evolución o avance con relación a la seguridad.

Conclusión: El entrenamiento del equipo y la aclaración por parte de la industria farmacéutica respecto del uso de las ampollas, es algo fundamental en la profilaxis de los accidentes y contaminaciones. Pero todavía es necesario descubrir nuevos sistemas de abertura de ampollas de forma más segura. No menos importante será la búsqueda de materiales seguros que sirvan de alternativa para el uso del vidrio.

Descriptores: ANESTESIOLOGÍA: Educación, Sguridad; EQUIPOS: Ampolla. 